\title{
Identification and GIS Analysis of Disasters Occuring in Landslide Prone Areas of Pakistan
}

\author{
Naseem Gilany* and Manzoor Hussain \\ School of Civil and Environment Engineering, National University of Science and Technology, Pakistan
}

Submission: January 31, 2019; Published: February 19, 2019

*Corresponding author: Naseem Gilany, School of Civil and Environment Engineering, National University of Science and Technology, H-12, Islamabad, Pakistan

\begin{abstract}
The north east area of Pakistan is characterized as highly prone to landslide hazard. To monitor such vast areas physically where there is high vulnerability of the hazard is very difficult. The purpose of this study was to identify the potentially dangerous landslides to downward settlements in GIS environment by utilizing remote sensing techniques. The study was conducted in north east areas of Pakistan where there are several human settlements which are endangered due to landslide hazard. The sudden slide of highly unstable mass adjoined with receding rocks occurs because of seismic shocks. The DEM is utilized to detect the flow course of landslides involving slope, elevation and orientation of the mountains. The study results show that settlements in north east of Pakistan are found more threatened in comparison with east region. Keeping in view the frequent land sliding activity in the region of study, the habitat is facing potential danger. The results of the study provide a platform for establishment of an early warning and monitoring system..
\end{abstract}

Keywords: Landslide; Disastrous; Geo-morphology

\section{Introduction}

In the north east region of Pakistan, the vulnerabilities of landslides demand preparedness and risk reduction response. In this research the identification and mapping of disasters like landslides in Pakistan is carried out. The landslides are triggered as a result of some natural and anthropogenic action mainly depending on the type of strata present along the slopes [1]. Major natural causes can be seismic activity (earthquake) and rainfalls whereas major anthropogenic cause is toe excavation without providing any adequate retaining structure. Type of strata present within the natural slopes which undergo frequent movements mainly consist of clay and weathered shale material with some thin layers of highly fractured and jointed sandstone [2]. Present study has been conducted to provide vulnerability assessment of the identified hazard prone areas. Detailed assessment of such areas has been carried out and site-specific analysis is presented in the study.

\section{Objective}

The foremost objective of this research is to carryout identification of the landslide hazard in north east area of Pakistan.

\section{Materials and Methods}

\section{Study area}

The study area comprises of the north east areas of Pakistan.

\section{Data set}

The data set used for the study purpose is as following:

a) LandSat TM Images of north east area of Pakistan within the substantial time span have been acquired from SUPARCO.

b) Topographic maps of Pakistan and SRTM data Digital Elevation Model of north east area of Pakistan.

c) Geomorphologic data of north east area of Pakistan acquired from geological Survey agency of Pakistan.

\section{Satellite image}

LandSat ETM data is used for the delineating with spectral differentiation. The remote sensing image data with a pixel size of 15 and $30 \mathrm{~m}$ is utilized for analysis of the north east area of Pakistan.

\section{Topographic maps}

Digital Elevation model (DEM) of north east area of Pakistan having $30 \mathrm{~m}$ resolution of SRTM data down loaded is utilized for obtaining the elevation, slope and aspect of the mountains hosting the landslide hazard.

\section{Methodology}

Identification of landslide prone areas to assess the landslide 
hazard is conducted with the help of geospatial analysis. Using height information obtained through DEMs orientation and slope maps are formed. The methodology used for the study is as following:

a) Study and acquisition of topographic maps and satellite images.

b) Capturing digital data of landslides from maps and imagery.

c) Comparative attributes database development of landslides of north east area of Pakistan.

d) Identification of potentially dangerous landslide sites.

\section{Results and Discussion}

The settlements, infrastructure and agricultural fields situated in downslopes of mountains are under continuous threat of potentially dangerous landslides which are very often in north east area of Pakistan [3]. Antecedent, landslide phenomenon comprehensive and accurate knowledge is of utmost importance. The ability of decision makers on adaption of risk mitigation measures and prone vulnerability will be enhanced with a detailed digital data repository of detailed knowledge of landslides happenings. This forms the basis for environmental studies and future climate change research.

\section{Geology and geomorphology of the study area}

Mountains in the area have very steep slopes and mostly contain sedimentary rocks and soil material. Sedimentary rocks present in the area mainly consist of sandstones and shale. The rocks are highly fractured, jointed and at placed are highly disintegrated due to weathering [4]. The soil material consists of range of material ranging from clay to boulder size material. Visual observation revealed that the fine matrix is susceptible to erosion especially where vegetative cover is absent. Trees, small bushes, shrubs, and grass is mostly present along the slopes except the places where debri flow usually occur as result of rainfall or snowmelt. Entire area is in highly tectonically active zone [5]. Most recent tectonic activity in the area was occurrence of disastrous Kashmir Earthquake on 8 Oct 2005 that has played havoc in the area and resulting in great loss to the human lives, livelihood, and damage to the properties.

\section{Nature of hazards present in study area}

Following different types of hazards which have been observed in the study area:

Snow-Slide Hazards: The areas with high altitudes usually get 8 to $12 \mathrm{ft}$ thick snowfall at an average from Nov to Feb every year. Snowmelt generally starts in March every year when temperature starts increasing whereas snow is almost completely cleared in the area by May every year. Snowmelt usually results in sliding of snow mass which as result takes along rock debris present along the slopes to the valley. Snow-slides generally follow the predefined channels / streams present along the slopes. The slides also carry debris material present along the slopes and deposit the sediments on downslope mostly near the toe [6]. These snow-slides depending on the type of slope and slide pattern poses threat to the settlements located within the effective range.

Landslide Hazards: The term landslide covers all slope movements that occur from natural or manmade causes except ground subsidence [7]. Different types of landslide hazards present in the area are as follow:

Rotational and Translational Landslides: Rotational landslides occur mostly in case of deep-seated failure whereas translational landslides occur in case of shallow failure. In study area, mostly translational landslides have been noticed. Failure is preceded by appearance of tension cracks on the upslope side. With widening of tension cracks, some settlement at the crown appears in the form of vertical or near vertical scarp. Heaving near the toe appears before complete failure. In case of translational landslide, movement generally takes place along a weaker layer that may be generally oriented parallel to the slope. Percolation of water into the tension crack results in considerable increase in the driving forces thus resulting in failure. Rate of movement of slope depends on the type of strata along which movement is taking place. In case of first-time movement, the clay and shale offer more resistance. Whereas for subsequent movement along the same surface the resistance decreases considerably because clays and shales have tendency of losing strength after moving by $2-3 \mathrm{ft}$.

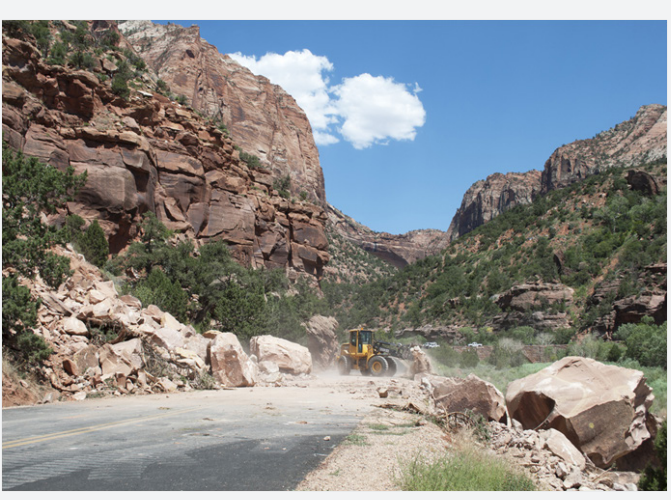

Figure 1: Rockfall on a road from the adjacent slope.

Rockfall. Rockfalls also occur in the study area. Because the natural slopes mostly contain soil deposits with some small to boulder size rock pieces present within the soil mass. It has been observed that such soil strata are highly susceptible to erosion. When water from the rainfall or snowmelt percolates into the soil, it softens up the soil strata. This results in reduction of soil strength thus dislodging the rock pieces and resulting in flow of such stones along the slope. In the process, some more rock pieces and debris from the slope also start flowing downslope. This process is rainfall and snowmelt related whereas no movement of rock pieces may be observed during dry period. Movement of some marginally stable rock pieces may also trigger as result of 
earthquake. In some areas where rock mass is present along the slopes, disintegrated rock pieces also keeps on falling down from the slopes. Areas susceptible to the rockfall may be kept under strict observation, more vigilance be exercised, and drills may be practiced for taking shelter or escaping from such locations on triggering of rockfalls (Figure 1). Rockfall protective mesh / draping nets can be placed along the slopes susceptible to this phenomenon, if the source is limited (Figure 2).

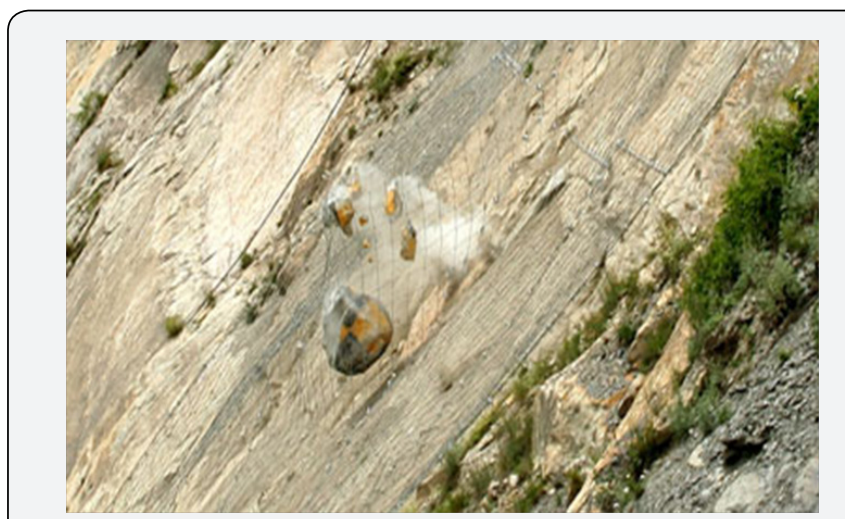

Figure 2: Rockfall protection mesh / draping net.

Debris Flow: A debris flow is a moving mass of loose mud, sand, soil, rock, water and air that travels down a slope under the influence of gravity. To be considered a debris flow the moving material must be loose and capable of "flow", and, at least 50\% of the material must be sand-size particles or larger. Some debris flows are very fast. In areas of very steep slopes debris flow can reach speeds of over $160 \mathrm{~km} /$ hour. However, many debris flows are very slow, creeping down slopes by slow internal movements at speeds of just one or two feet per year $(0.3$ to $0.6 \mathrm{~m}$ per year). Phenomena of debris flow are more frequent in the area. High current water from rainfalls and snowmelt while flowing downslope along naturally defined paths takes along relatively loose material coming in its way. Debris flow generally fans out near the toe thus blocking the roads and tracks. Debris avalanches have also been noticed along the roadsides. Any site present near the toe along the flowing path of debris is likely to be affected.

Mudflow: A mudflow is composed of mud and water involving "very rapid to extremely rapid surging flow" of debris that has become partially or fully liquified by the addition of significant amounts of water to the source material. Mudflows contain a significant proportion of clay, which makes them more fluid than debris flows; thus, they are able to travel farther and across lower slope angles. Minimize mudflow hazards, plant ground cover on slopes, build retaining walls, and build channels or deflection walls to direct flow around buildings.

Creep: The process by which soil slowly moves down a hillside is called "soil creep." It is one of the many natural events that cause mountains to be reduced to plains. Any other structure that is built on and supported by the creeping soil, such as a house, etc., will also move slowly downhill. This movement will result in both vertical (downward) and horizontal (outward) movement of the structure. The evidence for this movement includes tilting, cracking of concrete, and both horizontal and vertical separation across the cracks. Crooked trees, tilted poles/ fences and soil ripples are also evidencing of slope creep. The speed of the surface soil creep is measured in fractions of an inch per year. The steeper the slope, the faster the movement. Evidences of creep have also been noticed along the roadsides in the area. Soil creep can be stopped with properly placed retaining walls supported by the stable ground below the creep zone. Structures, including houses can be supported on deep foundations gaining their support in the stable earth below the creep zone thereby soil will continue to creep, but the structures will not be damaged by the soil movement.

\section{Detailed evaluation for landslide hazards}

The identification of the hazard prone areas in Pakistan's north east region has been done through image interpretation and further authenticated through detailed surveys. Detailed assessment for few of the settlement sites is as follow:

\section{Chakothi-Uri Crossing Point}

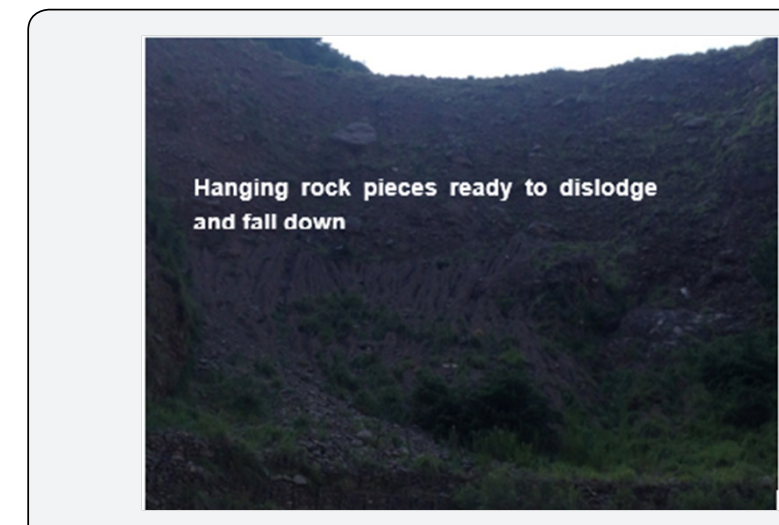

Figure 3: A closer view of rock susceptible area at CUCP.

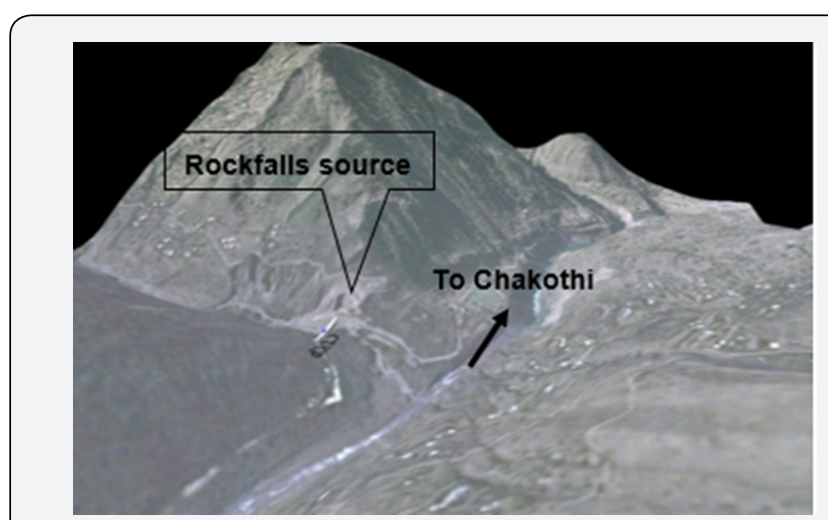

Figure 4: 3D View of CUCP.

Observations and Discussion. The location is just in front of the bridge at Chakothi-Uri Crossing Point (CUCP) on Pakistani side of Line of Control. Well designed and constructed retaining structures are intact along the Uri-Chakothi Road. Reportedly, some rockfall phenomena occur during rainfall period. The fine- 
grained soil is susceptible to erosion and scouring. Therefore, typical phenomena of rockfall as described before take place as result of wetting of soil especially during rainfall. Pieces of rock falls from the area near the top with relatively vertical face as marked on the photograph. A Check Post located on home side of the bridge is also vulnerable to the rockfalls. The length of road from bridge to the waiting area (reception point) on Pakistan side is also vulnerable to rockfalls phenomena (Figure $3 \& 4$ ).

\section{Devlian Landslide}

Observations and discussion: Devlian landslide zone are an active landslide zone which is present along Muzaffarabad Neelum Velley Road. The landslide affects about 300-400 meter of the road. The landslide occurred during 2005 Earthquake and is currently moving as a result of weathering of shale material. Shale is softened up upon interacting with the water. The weathered material slides along the slope and after hitting the road it goes down in the Neelum River (Figure 5 \& 6). It is a major landslide which needs huge resources to mitigate it effectively.

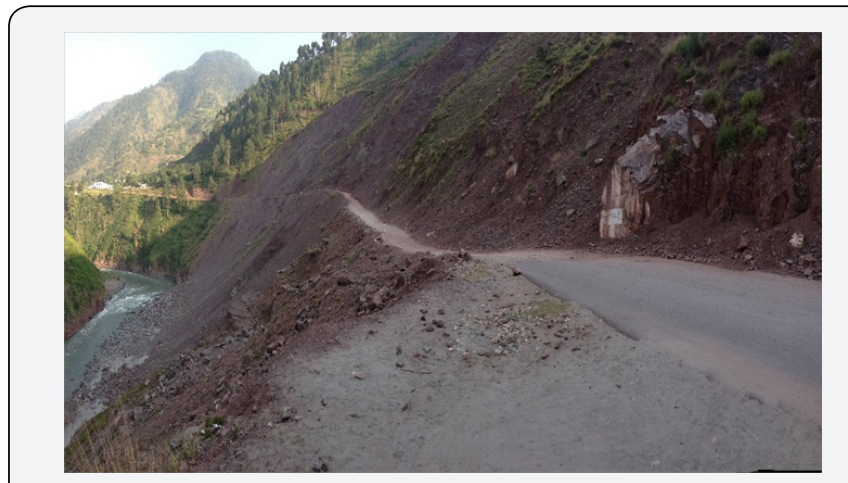

Figure 5: Devlian landslide on Neelum Valley Road.

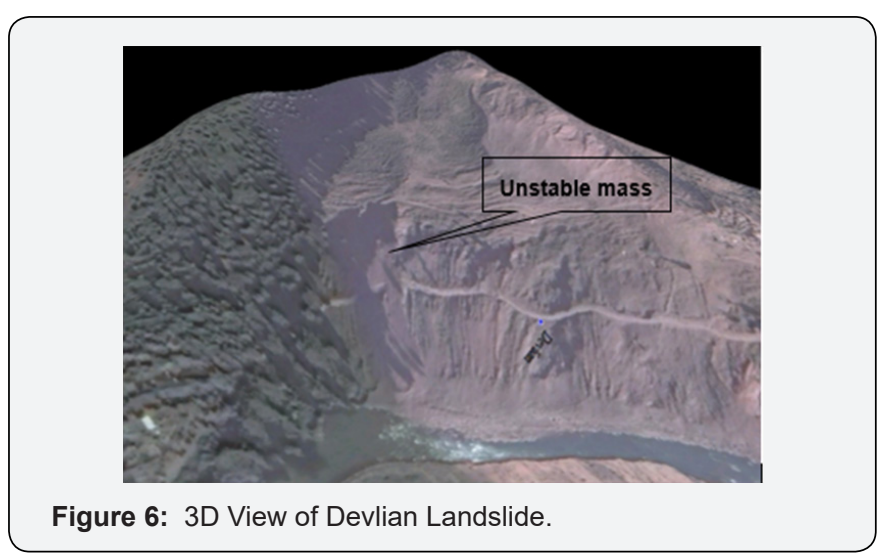

\section{Nezapir}

Observations and discussion: Nezapir are sited along a slope and is widely dispersed on the ridge. The location is under serious threat to landslide hazard. Evidences of landslide movement have been observed in the form of tension cracks on uphill side and movement near the slope toe. The tension cracks have undergone considerable widening and settlement in the order of few feet at the top scarp during rainfalls (Figure 7 \&
8). It is determined that the translation landslide with shallow failure is the case at Nezapir. Some evidences of landslide movement have also been observed on downslope. The strata present along the slope mainly consist of fine-grained material. When a snowfall accumulates on the slope or water percolates into the slope during rainfall or snowmelt, driving stresses will increase considerably whereas the resisting strength which has already been reduced to residual level will remain the same. This increase in the driving stresses when exceeds the resisting strength will result in triggering the landslide movement. Therefore, probability of landslide movement will increase during and/or after heavy rainfalls and during snowmelt period. The observations suggest that the location is highly vulnerable to landslide hazard and is under serious threat. Layout, pattern, and series of tension cracks suggest that landslide is active, and movement is taking place may be at very slow rate. Rate of movement may increase as a result of heavy rainfalls and snowmelt or sudden failure may occur as a result of some tectonic activity (earthquake).

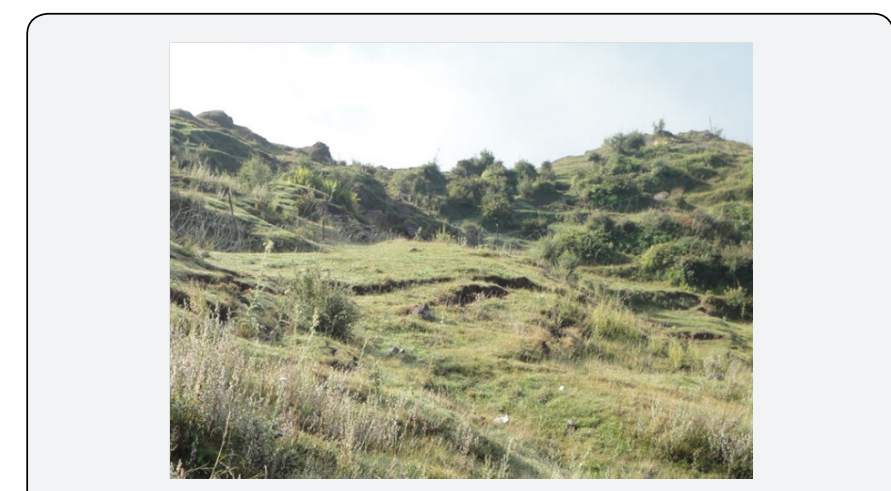

Figure 7: View showing a tension crack running about $400 \mathrm{~m}$ along the slope.

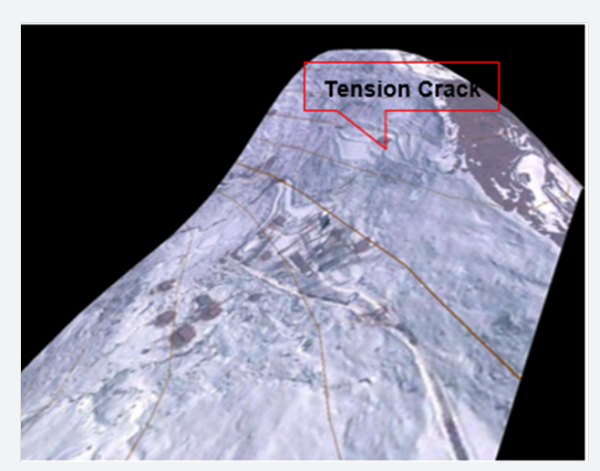

Figure 8: Digital Elevation Model (DEM) of Nezapir.

\section{Conclusion}

a) Although site-specific analysis has been carried out for each site following are generalized conclusions for the entire area:

b) Monitoring system of seismic activities be established at regional level. 
c) Snow melt results in sliding of snow mass which as result takes along rock debris present along the slopes to the valley.

d) Slopes within north east of Pakistan are steep but stable; vulnerable to land-slide hazards.

e) Land sliding and debris flows generally occur along predefined channels present along the slopes and poses threat to the settlements located on down slope or near the foothill.

f) Rock fall phenomena occur mostly in the study area; during and after rainfalls when soil loses its strength and results in dislodging of rock pieces, posing serious threat to the settlements located at the down slope.

g) Slopes in Kashmir areas mostly contain clay/ weathered shale material; weaker material, easy to slide when it interacts with water.

h) Steep slopes with clay/ shale are susceptible to erosion and as a result of flash floods get saturated and start moving as mudslide taking along debris present along the path.

\section{References}

1. Calkins JA, Offield TW, Abdulla SKM, Ali T (1975) Geology of the southern Himalaya in Hazara, Pakistan, and adjacent areas: U.S. Geological Survey Professional Paper 716C: 1-29.
2. Sato HP, Koarai M, Une H, Hasegawa H, Iwahashi J, et al. (2006) Interpretation of landslide distribution triggered by the Northern Pakistan earthquake on 8 October 2005 using 2.5-m-resolution SPOT 5 stereo imagery. Proceedings of the International Conference on October 8, 2005, earthquake in Pakistan, Islamabad, Pakistan, pp. 104106.

3. Schneider JF (2006) Earthquake triggered mass movements in northern Pakistan with special reference to the Hattian slide. In: Kausar AB, Karim T, Khan T (Eds.), Proceedings of the International Conference on October 8, 2005, earthquake in Pakistan, Islamabad, Pakistan, January 18-19, 2006, Islamabad, Pakistan, Geological Survey of Pakistan, p. 76-78.

4. Varnes DJ (1978) Slope movement types and processes. In: Schuster RL, Krizek RJ (Eds.), Landslides--Analysis and Control, Transportation research Board, National Academy of Science, Special Report 176, p. 11-33.

5. National Engineering Services Pakistan (NESPAK) (2010) Dam break study of Attabad landslide, Report to National Disaster Mitigation Authority Pakistan.

6. Hussain SH, Awan AA (2009) Causative mechanisms of terrain movement in Hunza valley, Geological Survey of Pakistan.

7. Daily pager reports from January to July 2010 from the database of National Disaster Mitigation Authority Pakistan.

\section{Your next submission with Juniper Publishers will reach you the below assets}

- Quality Editorial service

- Swift Peer Review

- Reprints availability

- E-prints Service

- Manuscript Podcast for convenient understanding

- Global attainment for your research

- Manuscript accessibility in different formats ( Pdf, E-pub, Full Text, Audio)

- Unceasing customer service

Track the below URL for one-step submission https://juniperpublishers.com/online-submission.php 